Article

\title{
Perspectives on the Direction of the Suncheon Bay National Garden from Local Residents and Non-Local Visitors
}

\author{
Moohan Kim ${ }^{1}$, Jong-Sang Sung ${ }^{2}$ and Jin-Wook Lee ${ }^{3, *}$ \\ 1 Bureau of Ecological Research, Division of Ecosystem Services and Research Planning, \\ National Institute of Ecology, Chungcheongnam-do 33657, Korea; moo7han@gmail.com \\ 2 Graduate School of Environmental Studies, Seoul National University, 1 Gwanak-ro, Gwanak-gu, \\ Seoul 08826, Korea; jssung@snu.ac.kr \\ 3 Environmental Planning Institute, Seoul National University, 1 Gwanak-ro, Gwanak-gu, Seoul 08826, Korea \\ * Correspondence: bamisland@gmail.com; Tel.: +82-10-5157-1045
}

Received: 22 August 2017; Accepted: 10 October 2017; Published: 12 October 2017

\begin{abstract}
As Korea's first national garden, the Suncheon Bay National Garden is a major tourist attraction and a space of enjoyment for visitors. However, in 2016 its sudden establishment necessitates many discussions and measures, and requires that it seek direction based on current perceptions for its continued use in the future. This study begins a search for that direction by examining perspectives of local residents and non-local visitors on the relationships between visitors' purposes, spatial needs, and required features. The research methodology included a survey administered to Suncheon residents and tourists on these factors. Results were analyzed by multiple correlation analysis and networking between the variables, and differences between Suncheon residents and non-local visitors were deduced; relationships among the factors were also verified. Both locals and visitors saw a need to emphasize garden experiences and education. The study also presents items that differ by respondent group. This study provides information that can be referred to when implementing management and plans for other national gardens.
\end{abstract}

Keywords: 1st Korean National Garden; correlation network analysis; sustainable tourism

\section{Introduction}

\subsection{Background and Purpose of Research}

In September 2016, the Suncheon Bay Garden was legally designated as the first South Korean national garden. The 111.2 ha public garden was created as infrastructure for the opening of the 2013 Suncheon Bay World Garden Exposition, after which it became a premier tourist attraction (see Figure 1). Amidst increased interest in demand the idea of national public gardens, the Korean Government amended the existing Creation and Furtherance of Arboretums Act to the Act on the Creation and Furtherance of Arboretums and Gardens in January 2015 [1]. There had not been any prior legislation on public garden creation before the revision, which laid the legal ground for the registration of public gardens, allocation of relevant budgets, and so forth [1]; in other words, it helped position national public gardens to better serve the public [1]. Following the amendment, Suncheon Bay Garden, formerly the venue for the World Garden Exposition (20 April-20 October 2013), which had opened as a standalone attraction on 20 April 2014, was designated the first national garden in Korea on 5 September 2016 [1].

Although its attributes and main use have changed greatly in a short period there has, however, been a lack of discussion about the status of the national public garden. Until now, research on the Suncheon Bay Garden has focused on user satisfaction and on issues regarding the use of the exposition area. Kim and Song studied the condition of visitors and their satisfaction levels during the Expo and 
researched the factors influencing the condition and satisfaction [2]. Jang and Choi collected blogs posts written by visitors during the garden exposition to analyze their perceptions [3]. Song et al. searched for future uses based on evaluations of the exposition made by attendees [4].

However, work is also needed to repeatedly analyze plan implementation for sustainable use and user perception of the public garden. Additionally, prior research was primarily conducted among non-local visitors; however, studies show that tourism development that excludes local residents can result in distrust among local residents and can lead to tourist dissatisfaction [5-8]. In light of these findings, it seems necessary to take into account the opinions of local residents in addition to visitors. The convergence of internal and external opinions can make possible the establishment of goals for sustainable use and management by allowing consideration of problems that may occur as a result of conflict between local residents and non-local visitors [9].

The national garden must progress as a sustainable use of space by performing the role of a national public good while also cementing itself as a space for local residents. To this end, the present study intends to present primary reference materials to inform the sustainable use of the Suncheon Bay National Garden and the development of other national gardens; specifically, it will collect and discuss differences and commonalities in perceptions between locals and visitors regarding the garden.
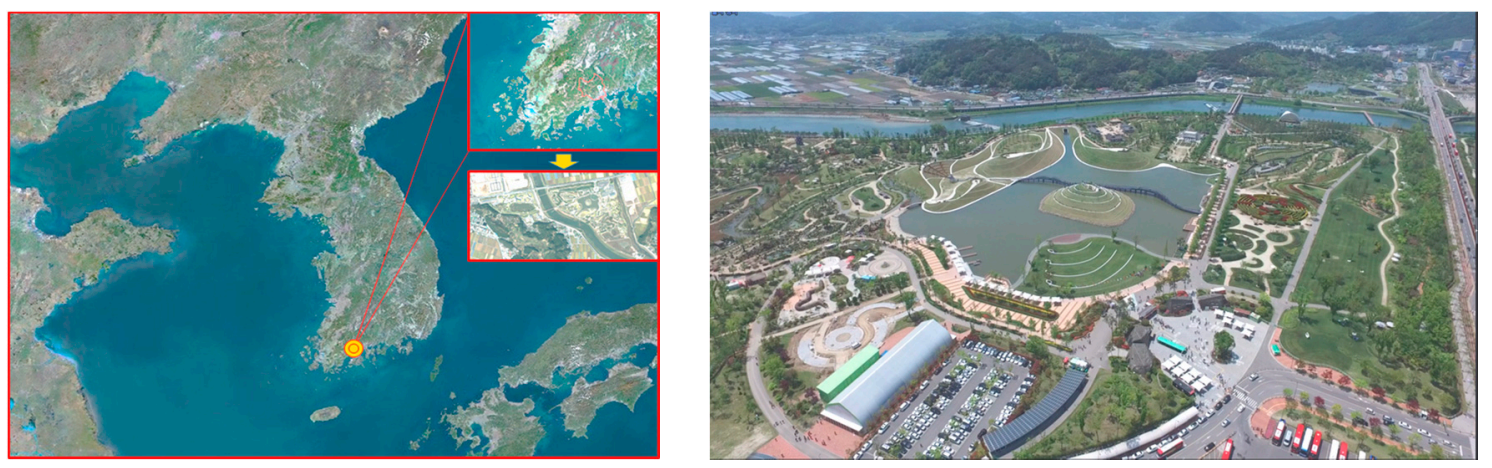

Figure 1. Site location and bird's eye view of the first Korean national garden (area: 111.2 ha).

\subsection{Theoretical Considerations and Literature Review}

The Garden Act stipulates that a garden is "a space where continuous management takes place through the displaying and arrangement, or cultivation and growth of plants, soil, and facilities (including sculptures)" [1]. A national garden is defined as a garden that the state develops and operates. However, the concept of a national garden is a novel one, which leads to contemplation of its meaning [1].

The Windsor Castle National Garden in England and the National Garden of Japan are two examples of gardens designated as national gardens. The Windsor Castle Garden around the Imperial Palace is a royal garden, a national asset within the Windsor Great Park [10]. The Shinjuku Gyoen National Garden of Japan is a city park; when it was thus established, the state was able to repair its royal homes and gardens [11].

Although lacking the title of national garden, some botanical gardens also perform the role of a national symbol for their country. Sometimes this was an intentional part of the purpose of the garden's development; other times, it was an organic result of interest and activity among locals and tourists. The National Botanic Garden of Wales is an example of the first type, developed as a symbol of Welsh nationalism; for the latter, we may consider the Kew Gardens in London, the U.S. Botanic Garden in Washington, the Botanic garden in Amsterdam [12], and the Gardens by the Bay in Singapore [13].

In an expanded meaning, a garden is described as a public place for rest and leisure [14]. A garden is an enclosed space $[15,16]$ that, inside its walls, floor, and ceiling, is made up of natural elements-a room in an outside space [17]. A garden is also a place that puts focus on leisure, a place to enjoy and appreciate $[18,19]$, and a place to experience nature and culture $[20,21]$. 
A public garden is developed as a region borne from an established garden that both local residents and non-resident visitors visit and spend time in for the purpose of education, experiences, exhibitions, or a change of scenery [12]. Thus, a national garden can be explained as a space that local residents often visit [22] and a tourist attraction for non-resident visitors.

Differences in perceptions of attractions between local residents and non-resident visitors are a key issue for sustainable tourism [23,24]. Local residents and outside visitors often have very different values and perceptions of a target area [25-27] and exhibit different use patterns [28]. Poudel et al. [25] compared residents and tourists who visited a protected area within a national park and found that they had different sets of positive and negative perceptions about the space.

However, previous studies in sustainable tourism have mostly focused on the relationship between tourism and the environment [29]. Studies of national parks and botanic gardens have explored issues in planning and management [30,31], conservation and diversity of plant species [32,33], establishment of organizational identity [34], the gardens' role in social integration [35], education for protection of the environment and ecosystems [34], the potential of sustainable, ecological tourism at the gardens [36], and so forth. However, there has been little study into the establishment of a detailed direction for the garden space; to establish such a direction and establish a better place, an examination of the perceptions and needs of residents and outside visitors could suggest what can be done [37].

This study attempts to examine these views of residents and non-resident visitors at Suncheon Bay National Garden: the purpose of their visit, spatial needs, perceptions of the nature of a national garden, and how these matters interrelate. Thereby, the aim is to identify the most desirable direction for a sustainable national garden and complement existing studies, which have failed to show how to use national garden better in detail and to establish sustainable strategies. In addition, this study intends to move beyond the concerns of previous studies with conservation plans, management, and the role of the place to suggest measures for sustainable tourism from the perspective of users.

\section{Materials and Methods}

The study used a paper survey to collect answers from local residents of Suncheon and non-resident visitors to the Suncheon Bay National Garden regarding plans for the garden, amenities that are needed, and their reason for visiting. To survey Suncheon residents, the study worked with town administrative offices and community service centers; and a total of 370 surveys were distributed among these locations. For non-resident visitors, a survey booth was set up at the east exit of the garden, and five landscape architecture graduate students trained in pilot surveys and survey methodology administered the questionnaires one-on-one. In both groups, a gift valued around 5000 won (about \$4 USD) was provided to those who filled out the questionnaire.

Participants answered study questions regarding (1) the visit purpose (information, tourism, education, relaxation); (2) spatial needs (space for educational experiences, canteen, relaxation spaces, cafeterias); and (3) items that the garden needed to strengthen (Korean identity, improved design, garden education, garden experiences, promotion, amenities, and information about the garden) (see Figure 2). These questions were changed to dummy variables and analyzed. 


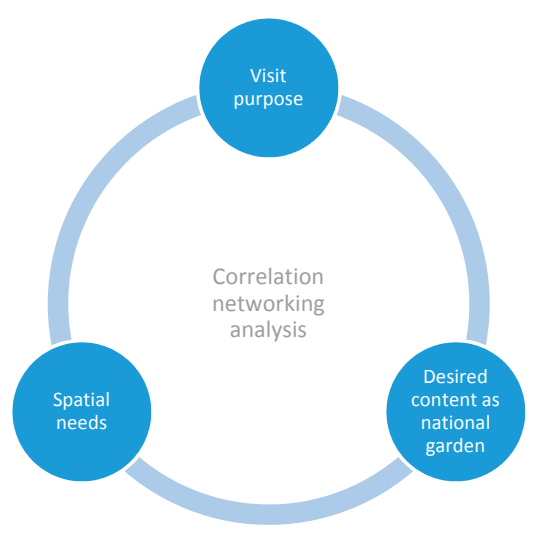

Figure 2. Research analysis framework.

The software package SPSS, v. 22 (IBM, Armonk, NY, USA), was used to analyze survey results for visiting purpose, facilities needed, and plans for the garden, and a multivariate correlation analysis was carried out. The study deduced more abundant data by visualizing relationships among the survey content, using a concept map program called Cmap (v. 6.02). Cmap, a tool designed to make it easier to create diagrams, has been used by the US Environmental Protection Agency to visually analyze complicated relationships [38]. This is correlation networking analysis, which visualizes and analyzes connections among various factors. Correlation networking analysis is an analytical method for analyzing the relationships among several factors [39], and helping to make different choices of the soft threshold [40].

A total of 275 local residents participated in the survey, among whom $143(52 \%)$ were female and $241(87.6 \%)$ were between 20 and 60 years of age, $27(9.8 \%)$ were over 60 years of age, and seven $(2.5 \%)$ were under the age of 20. Of the Suncheon citizens who visited community centers and were invited to participate by employees, $95 \%$ agreed to do so. A total of 213 visitors to the garden participated in the survey (see Appendix A). Non-resident visitors who visited the target place and came out through the eastern gate, the main exit, were randomly sampled; $92 \%$ of them responded to the survey. Of them, $158(73.8 \%)$ were female, and the age distribution was as follows: 27 participants $(12.6 \%)$ were under 20, while 124 participants (58\%) were between 20 and 60, and 63 participants $(29.4 \%)$ were over 60.

\section{Results and Discussion}

\subsection{Non-Resident Visitors' Concerns}

The perception survey covered purpose of visit, spatial needs, and what the garden should focus on being a national garden. A visual analysis of the correlation analysis results was carried out for results on each of these questions, and correlations among the data were verified.

The following items exhibited a positive correlation in the findings for outside visitors (see Figure 3). Information acquisition as a motive for visiting was correlated with perceptions that Korean identity was a facet that the national garden needed to strengthen, and tourism as a motivation with the view that the "garden experience" should be strengthened. The correlation between information acquisition (purpose of visit) and strengthening of Korean identity (item to be improved) among non-resident visitors showed that information about national identity is important to a garden. It can be inferred that they expect a national garden to provide areas with native tree and plant species and relevant information. The correlation between tourism (purpose of visit) and strengthening of garden experience (item to be improved) indicates that outside visitors prefer interactive tourism, meaning the garden should not be just decorative, but should offer opportunities for hands-on experiences. 
Non-resident visitors also drew a relationship between strengthening of Korean identity and design improvements, to the point of collinearity. This suggests that a design that emphasizes Korean identity for non-resident visitors could be implemented when developing future national gardens.

Negative correlations among seven items were also verified. With regard to visit purpose, visitors perceived tourism and education as opposed, and for spatial needs, they perceived canteen and spaces for educational experiences as opposed. Canteen was also opposed to strengthening of Korean identity. Within the spatial needs category, there was a negative correlation between spaces for educational experiences and improving amenities. Lastly, for plans for the national garden, strengthening of garden experiences showed negative correlations with more amenities and design improvements. This indicates that the quality of the experience is more important than the garden's external design or facilities; therefore, it should be managed in such a way as to enhance the quality of the experience.

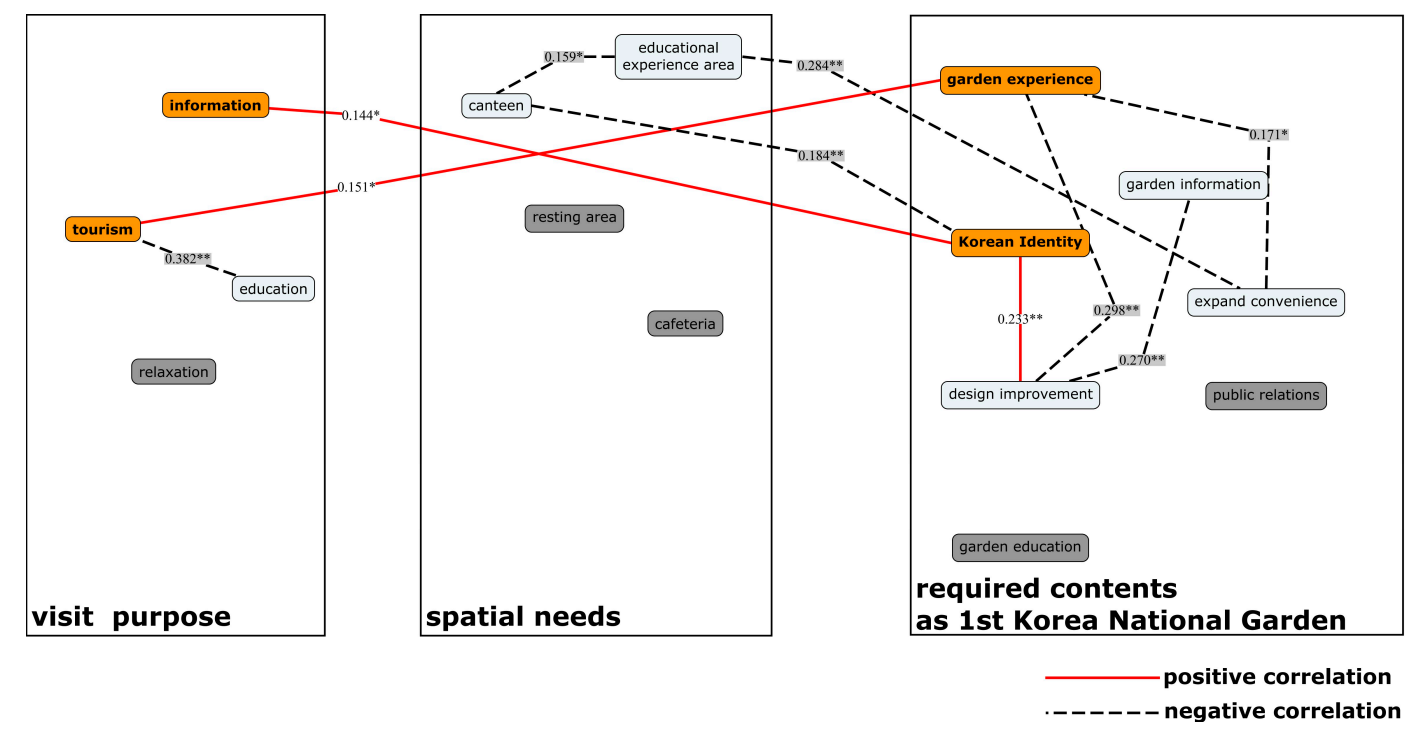

Figure 3. Non-residents' correlation network analysis results $\left({ }^{*} p<0.05,{ }^{* *} p<0.01\right)$.

\subsection{Local Residents' Concerns}

Several items showed different relations among Suncheon residents than among non-resident visitors (see Figure 4). First, residents whose visiting purpose was information acquisition saw space for educational experiences and a canteen as spatial needs. These spatial needs were also connected with garden experiences and improving the information provided, both mentioned as items that needed to be strengthened. Last, residents connected strengthening of garden information provided and strengthening of garden education. This can verify that Suncheon residents look to the garden for information, which is connected to their visiting purposes, spatial needs, and plans for the national garden. Information as a motivation for visiting was also connected with improving garden information and with a canteen and a cafeteria; thus, they view cafeteria functions as important. For visiting purpose, information and education both had negative correlations with relaxation, a finding also reflected in the data on items that the national garden needed to strengthen, where improving garden education had a negative correlation with improving amenities, while improving promotion had a negative correlation with improving garden experiences. Another issue is the question of whether these should be distinguished. 


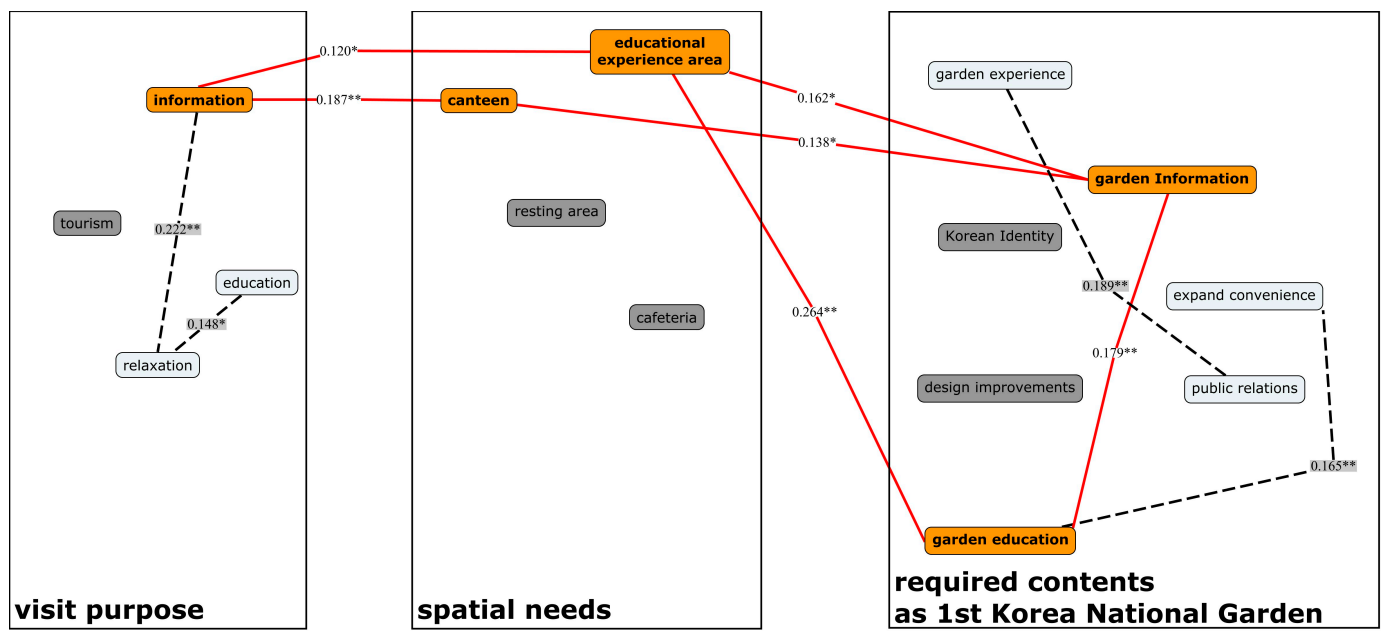

positive correlation

- - - - negative correlation

Figure 4. Local residents' correlation networking results $\left({ }^{*} p<0.05,{ }^{* *} p<0.01\right)$.

\subsection{Differences between Findings for Non-Residents and Local Residents}

Non-resident visitors drew a connection between information acquisition and strengthening Korean identity as visiting purposes. Suncheon residents, however, mentioned that a specific space was needed for educational experiences especially if their purpose for visiting was to acquire information. This suggests that non-resident visitors expect information on Korean identity and Korean design from a national garden. On the other hand, residents regarded education about and information on the garden itself as very important. In other words, they perceive a national garden not as a primarily symbolic place, in the way visitors did, but as a source of information and education, as well as a useful place closely related to their life. Regarding spatial needs, residents also drew connections between a space for educational experiences and garden information as visit purpose and desired improvement, whereas non-resident visitors drew a connection between improving garden experiences and tourism as a visiting purpose. In other words, on the whole, residents prefer acquiring useful information while visitors from outside want to have a tour and gain experiences.

Residents generally made demands more closely related to practical life, such as obtaining information and having first-hand experiences in the garden; conversely, outside tourists drew a connection between garden experiences and tourism, and perceived the national garden as a break from real life (see Table 1). This indicates that a new experience area should both provide interesting hands-on events for outside visitors and educational programs for residents.

There were also differences in the negative correlations. Whereas visitors perceive an opposition between tourism and education, residents perceive clashes between relaxation and information/education. With regard to improving garden experiences, non-resident visitors perceive a negative correlation between improving amenities and improving design, while residents perceive a negative correlation between improving promotion and improving garden experiences. Given these findings, Table 1 breaks down desirable attributes for a national garden that satisfies everyone. 
Table 1. Difference in correlation results between visitors and local residents.

\begin{tabular}{|c|c|c|c|c|c|c|}
\hline & \multicolumn{3}{|c|}{ Non-Resident Visitors } & \multicolumn{3}{|c|}{ Local Residents } \\
\hline \multirow{5}{*}{$\begin{array}{l}\text { Positive } \\
\text { Correlation }\end{array}$} & $\Delta$ Information & - & $\star$ Korean Identity & $\Delta$ Information & - & $\begin{array}{l}\text { Educational } \\
\text { experience area }\end{array}$ \\
\hline & . & . & . & . & . & . \\
\hline & . & . & . & $\begin{array}{l}\text { Educational } \\
\text { experience area }\end{array}$ & - & $\star$ Garden education \\
\hline & . & . & . & $\bullet$ Cafeteria & - & $\star$ Garden information \\
\hline & $\star$ Korean Identity & - & $\begin{array}{c}\star \text { Design } \\
\text { Improvement }\end{array}$ & . & . & . \\
\hline \multirow{7}{*}{$\begin{array}{l}\text { Negative } \\
\text { Correlation }\end{array}$} & $\Delta$ Tourism & - & $\Delta$ Education & $\Delta$ Information & - & $\Delta$ Relaxation \\
\hline & $\bullet$ Cafeteria & - & $\star$ Korean Identity & . & . & . \\
\hline & $\begin{array}{l}\text { Educative } \\
\text { experience area }\end{array}$ & - & $\begin{array}{l}\star \text { Expand } \\
\text { convenience }\end{array}$ & . & . & . \\
\hline & . & . & . & . & . & . \\
\hline & $\star$ Garden experience & - & $\begin{array}{l}\star \text { Expand } \\
\text { convenience }\end{array}$ & $\star$ Garden experience & - & $\star$ Public relations \\
\hline & $\star$ Garden experience & - & $\begin{array}{c}\star \text { Design } \\
\text { Improvement }\end{array}$ & $\star$ Garden education & - & $\star$ Expand Convenience \\
\hline & $\star$ Garden Information & - & $\begin{array}{c}\star \text { Design } \\
\text { Improvement }\end{array}$ & 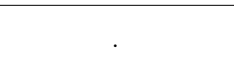 & . & . \\
\hline
\end{tabular}

$\Delta$ Visit Purpose, $\bullet$ Spatial Need, $\star$ Desired Aspect—showing linkage between left and right.

\subsection{Common Data between Visitors and Locals}

When the purpose of a visit is education, among other items that exhibit a positive correlation, improving garden education is expected of the national garden. However, since demands for a space for educational experiences are connected with improving garden experiences, a connection must also be drawn between garden experiences and garden education as visit purpose and as spatial needs (see Figure 5).

Next, relaxation and information showed negative correlations with tourism within the visiting motivations, indicating the need for a choice between whether the national garden should function as a tourist site, or whether it should be a place that emphasizes relaxation and information, or try to fulfill both roles, perhaps at different locations in the garden.

Both residents and visitors showed negative correlations between relaxation space and a cafeteria, relaxation and a canteen, space for educational experiences and a cafeteria, and educational experience spaces and relaxation spaces. This can be used as a reference for determining how to organize future national garden spaces and help them provide a differentiated or integrated character, for example including each of these areas. There were also negative correlations between opinions on the future direction of the national garden: between garden education and strengthening Korean identity, between improving garden education and improving design; between improving garden experiences and strengthening Korean identity; between providing improvements in garden-related information and strengthening Korean identity; between providing improvements in garden-related information and improving amenities; between improving promotion and improving design; and between improving promotion and improving amenities. This shows complex and oppositional relationships among content provision in different areas. 

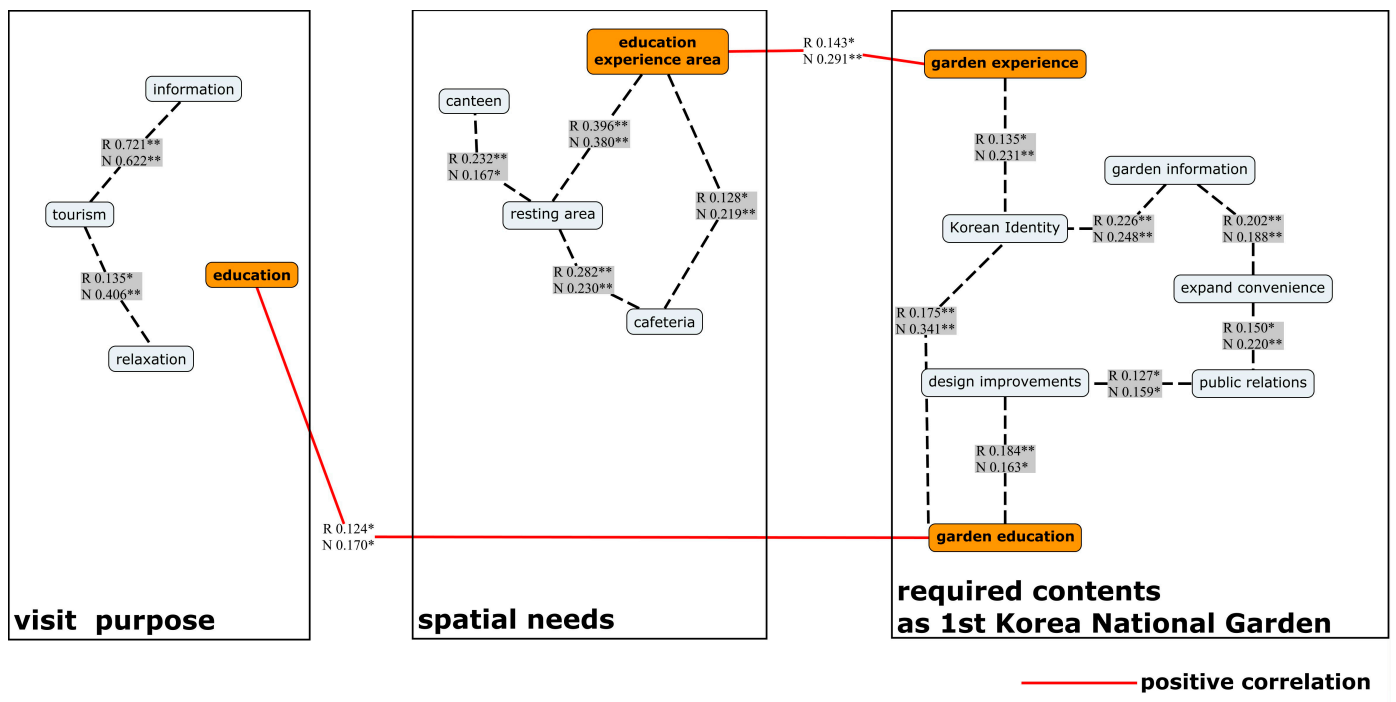

------ negative correlation

Figure 5. Common correlations in networking results ${ }^{*} p<0.05$, ${ }^{* *} p<0.01$, R: residents, $\mathrm{N}$ : non-resident visitors).

\section{Conclusions}

The above information should be referenced when establishing goals for the national garden. Garden experience and education were verified to be items that the national garden should prioritize to satisfy both non-local visitors and local residents, along with different specific items pertaining to only one or the other of these groups.

Although this study has the limitations attendant on the use of face-to-face surveys and time of study, it is meaningful for the way it verified the correlations between variables related to visiting purpose, spatial needs, and identity strengthening through correlation network analysis and gave a multilayered analysis of perceptions. This allows us to visualize the responses on purpose of visit, necessary areas, and direction as a national garden through correlation analysis, thereby summarizing the complex relations neatly. These findings are expected to broaden knowledge to promote sustainable tourism by understanding different perceptions of different user groups and setting up sustainable strategies to better utilize the space. With its recent designation as a national garden, various spaces in Suncheon Bay Garden are being restructured, and a long-term plan is required; the study of the perceptions of the respondents in this study will have considerable meaning in this regard and in the continued popularity of the garden. This study can also serve as primary reference data when developing future national gardens, and should be followed by a further survey determining needs based on demographic characteristics such as age and gender.

This study will help plan for the sustainable use and management of other national gardens by considering both the opinions of residents and non-resident visitors.

Acknowledgments: This research was supported by Suncheon-si local government. We would like to thank the graduate student assistants from Seoul National University (Sung-Ah Cho, Bo-Geum Kang, Jin Kim, Jin-Young Kim, and Yeon-Whan Yoo), the company Given-Zone QX, Professor Yong-Hoon Son, and Suncheon-si local officers.

Author Contributions: Moohan Kim and Jin-Wook Lee conceived, designed the research, and wrote the paper. Moohan Kim analyzed the data; Jin-Wook Lee revised the analyzed data; and Jong-Sang Sung proofread and revised the manuscript. All authors have read and approved the final manuscript.

Conflicts of Interest: The authors declare no conflict of interest. 


\section{Appendix A}

(i) What is the purpose of visiting this place? (information/tourism/education/relaxation)

(ii) Which space is the most needed for the use of this place? (canteen/educational experience area/resting area/cafeteria)

(iii) Which element is most vital for the first national garden? (garden experience/garden information /Korean identity/design improvement/expand convenience/public relations/garden education)

\section{References}

1. National Law Information Center. Available online: http://www.law.go.kr/lsSc.do?menuId=0\&subMenu= $1 \&$ query $=\% \mathrm{EC} \% \mathrm{~A} 0 \% 95 \% \mathrm{EC} \% 9 \mathrm{~B} \% 90 \% \mathrm{~EB} \% \mathrm{~B} 2 \% 95 \#$ undefined (accessed on 6 September 2017).

2. Kim, B.M.; Song, K. The analysis on satisfaction and re-visiting factors in Suncheon Bay Garden Expo. Tour. Inst. Northeast Asia 2014, 24, 77-93.

3. Jang, M.-J.; Choi, J.-M. The implication and recognition of International Garden Exposition Suncheon Bay Korea 2013 on Blogs. J. Korean Inst. Landsc. Archit. 2014, 42, 60-75. [CrossRef]

4. Song, T.G.; Ahn, K.H.; Seo, S.C.; Kim, E.I. A study of future utilization and visitor perceptions of the Suncheon Bay International Garden Expo 2013. J. Recreat. Landsc. 2014, 8, 33-42.

5. Allen, L.R.; Long, P.T.; Perdue, R.R.; Kieselbach, S. The impact of tourism development on residents' perceptions of community life. J. Travel Res. 1988, 27, 16-21. [CrossRef]

6. Cooke, K. Guidelines for socially appropriate tourism development in British Columbia. J. Travel Res. 1982, 21, 22-28. [CrossRef]

7. Davis, D.; Allen, J.; Cosenza, R.M. Segmenting local residents by their attitudes, interests, and opinions toward tourism. J. Travel Res. 1988, 27, 2-8. [CrossRef]

8. Johnson, J.D.; Snepenger, D.J.; Akis, S. Residents' perceptions of tourism development. Ann. Tour. Res. 1994, 21, 629-642. [CrossRef]

9. Jang, H.C. Tourist Behavior; KNOU Press: Seoul, Korea, 2015; ISBN 9788920926037.

10. Windsor Garden Castle. Available online: https:/ / www.windsor.gov.uk (accessed on 9 September 2017).

11. Shinjuku Gyoen National Garden. Available online: https://www.env.go.jp/garden/shinjukugyoen/ english/1_intro/history.html (accessed on 9 September 2017).

12. Benfield, R. 2013 Garden Tourism; CAB International: Boston, MA, USA, 2013; ISBN 978-1-78064-195-9.

13. National Parks Board. Available online: https:/ /www.nparks.gov.sg/news/2007/11/singapores-gardensby-the-bay-project-on-track-with-groundbreaking-ceremony (accessed on 9 September 2017).

14. Oxford English Dictionary. Available online: https:/ /en.oxforddictionaries.com/ (accessed on 9 September 2017).

15. Clifford, D. History of Garden Design, 2nd ed.; Faber \& Faber: London, UK, 1966; ISBN 978-0-571-06810-4.

16. Gerlach-Spriggs, N.; Kaufman, R.; Warner, S.B., Jr. Restorative Gardens: The Healing Landscape; Yale University Press: New Haven, CT, USA, 2004; ISBN 978-0-300-10710-4.

17. Stigsdotter, U.; Grahn, P. What makes a garden a healing garden. J. Ther. Hortic. 2002, 13, 60-69.

18. Hunt, J.D. Greater Perfections: The Practice of Garden Theory; University of Pennsylvania Press: Philadelphia, PA, USA, 2000; ISBN 978-0-8122-3506-7.

19. Sung, J.S. Green-health topology. J. Environ. Stud. 2014, 53, 71-79.

20. Marcus, C.C. The garden as metaphor. In The Meaning of Gardens; Francis, M., Hester, R.T., Eds.; The MIT Press: Cambridge, MA, USA, 1992; pp. 26-33, ISBN 9780262061278.

21. Rowe, P.G. Design Thinking; MIT Press: Cambridge, MA, USA, 1991; ISBN 978-0-262-68067-7.

22. Ballantyne, R.; Packer, J.; Hughes, K. Environmental awareness, interests and motives of botanic gardens visitors: Implications for interpretive practice. Tour. Manag. 2008, 29, 439-444. [CrossRef]

23. Nunkoo, R.; Smith, S.L.; Ramkissoon, H. Residents' attitudes to tourism: A longitudinal study of 140 articles from 1984 to 2010. J. Sustain. Tour. 2013, 21, 5-25. [CrossRef]

24. Cole, S. Information and empowerment: The keys to achieving sustainable tourism. J. Sustain. Tour. 2006, 14, 629-644. [CrossRef]

25. Poudel, S.; Nyaupane, G.P.; Budruk, M. Stakeholders' perspectives of sustainable tourism development: A new approach to measuring outcomes. J. Travel Res. 2016, 55, 465-480. [CrossRef] 
26. Maharana, I.; Rai, S.C.; Sharma, E. Valuing ecotourism in a sacred lake of the Sikkim Himalaya, India. Environ. Conserv. 2000, 27, 269-277. [CrossRef]

27. Yacob, M.R.; Radam, A.; Shuib, A. A contingent valuation study of marine parks ecotourism: The case of Pulau Payar and Pulau Redang in Malaysia. J. Sustain. Dev. 2009, 2, 95-105. [CrossRef]

28. Eagles, P.F.; McCool, S.F. Tourism in National Parks and Protected Areas: Planning and Management; CABI: Wallingford, UK, 2002; ISBN 0851995896.

29. Boyd, S.W. Tourism, national parks and sustainability. In Tourism and National Parks: Issues and Implications; Butler, R.W., Boyd, S.W., Eds.; Wiley: London, UK, 2000; pp. 161-186, ISBN 0471988944.

30. Pigram, J.J.J.; Sundell, R.C. National Parks and Protected Areas: Selection, Delimitation, and Management; Centre for Water Policy Research, University of New England: Biddeford, ME, USA, 1997; ISBN 9781863894012.

31. Nelson, J.G.; Serafin, R. National Parks and Protected Areas: Keystones to Conservation and Sustainable Development; Springer: Berlin, Germany, 2013; p. 40, ISBN 978-3-642-60907-7.

32. Donaldson, J.S. Botanic gardens science for conservation and global change. Trends Plant Sci. 2009, 14, 608-613. [CrossRef] [PubMed]

33. Walters, S.M. The role of Mediterranean botanic gardens in plant conservation. Webbia 1979, 34, $109-116$. [CrossRef]

34. Johnson, S. Reconceptualising gardening to promote inclusive education for sustainable development. Int. J. Incl. Educ. 2012, 16, 581-596. [CrossRef]

35. Vergou, A.; Willison, J. Relating social inclusion and environmental issues in botanic gardens. Environ. Educ. Res. 2016, 22, 21-22. [CrossRef]

36. Sutherland, L.A. Broadening the view of ecotourism: Botanic gardens in less developed countries. In Ecotourism and Environmental Sustainability: Principles and Practice; Hill, J., Gale, T., Eds.; Ashgate Publishing: Farnham, UK, 2009; pp. 197-222, ISBN 978-0-7546-7262-3.

37. Boley, B.B.; McGehee, N.G.; Perdue, R.R.; Long, P. Empowerment and resident attitudes toward tourism: Strengthening the theoretical foundation through a Weberian lens. Ann. Tour. Res. 2014, 49, 33-50. [CrossRef]

38. USA EPA (United States Environmental Protection Agency). Available online: https://archive.epa.gov / ged/tutorial/web/html/index.html (accessed on 9 September 2017).

39. Duran-Pinedo, A.E.; Paster, B.; Teles, R.; Frias-Lopez, J. Correlation network analysis applied to complex biofilm communities. PLoS ONE 2011, 6, e28438. [CrossRef] [PubMed]

40. Zhang, B.; Horvath, S. A general framework for weighted gene co-expression network analysis. Stat. Appl. Genet. Mol. Biol. 2005, 4, 17. [CrossRef] [PubMed] 